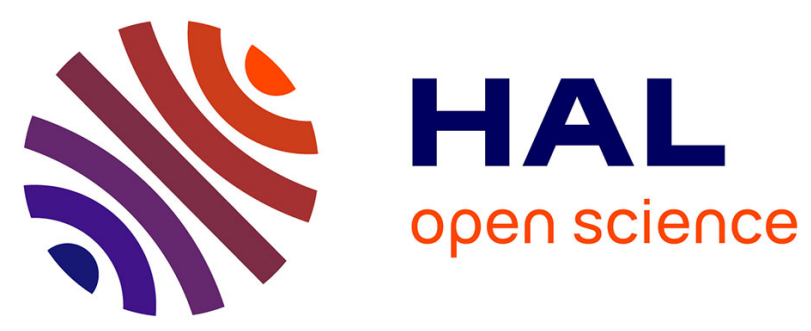

\title{
Carburization of austenitic and ferritic steels in carbon-saturated sodium: preliminary results on the diffusion coefficient of carbon at $873 \mathrm{~K}$
}

Marie Romedenne, Fabien Rouillard, Brigitte Duprey, Didier Hamon, Michel Tabarant, Daniel Monceau

\section{To cite this version:}

Marie Romedenne, Fabien Rouillard, Brigitte Duprey, Didier Hamon, Michel Tabarant, et al.. Carburization of austenitic and ferritic steels in carbon-saturated sodium: preliminary results on the diffusion coefficient of carbon at $873 \mathrm{~K}$. Oxidation of Metals, 2017, vol. 87 ( $\left.\mathrm{n}^{\circ} 5-6\right)$, pp. 643-653. $10.1007 / \mathrm{s} 11085-017-9733-5$. hal-01579031

\section{HAL Id: hal-01579031 \\ https://hal.science/hal-01579031}

Submitted on 30 Aug 2017

HAL is a multi-disciplinary open access archive for the deposit and dissemination of scientific research documents, whether they are published or not. The documents may come from teaching and research institutions in France or abroad, or from public or private research centers.
L'archive ouverte pluridisciplinaire HAL, est destinée au dépôt et à la diffusion de documents scientifiques de niveau recherche, publiés ou non, émanant des établissements d'enseignement et de recherche français ou étrangers, des laboratoires publics ou privés. 


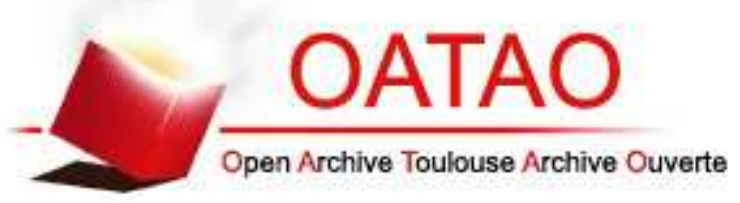

\section{Open Archive TOULOUSE Archive Ouverte (OATAO)}

OATAO is an open access repository that collects the work of Toulouse researchers and makes it freely available over the web where possible.

This is an author-deposited version published in : http://oatao.univ-toulouse.fr/ Eprints ID : 18113

To link to this article: DOI: $10.1007 / \mathrm{s} 11085-017-9733-5$

URL: http://dx.doi.org/10.1007/s11085-017-9733-5

To cite this version: Romedenne, Marie and Rouillard, Fabien and Duprey, Brigitte and Hamon, Didier and Tabarant, Michel and Monceau, Daniel Carburization of austenitic and ferritic steels in carbon-saturated sodium: preliminary results on the diffusion coefficient of carbon at $873 \mathrm{~K}$. (2017) Oxidation of Metals, vol. 87 (n 5-6). pp. 643-653. ISSN 0030-770X

Any correspondence concerning this service should be sent to the repository administrator: staff-oatao@ listes-diff.inp-toulouse.fr 


\title{
Carburization of Austenitic and Ferritic Steels in Carbon-Saturated Sodium: Preliminary Results on the Diffusion Coefficient of Carbon at $873 \mathrm{~K}$
}

\author{
Marie Romedenne ${ }^{1}$ (D) Fabien Rouillard ${ }^{1}$. \\ Brigitte Duprey $^{1} \cdot$ Didier Hamon $^{2} \cdot$ Michel Tabarant $^{3}$. \\ Daniel Monceau ${ }^{4}$
}

\begin{abstract}
Three commercial steels were exposed to carbon-saturated sodium at $873 \mathrm{~K}$ for durations up to $5000 \mathrm{~h}$. Analyses by optical microscopy, infrared-inductive carbon combustion, electron probe microanalysis and glow discharge optical emission spectrometry revealed important carburization of the steels. The carbon concentration at the metal-sodium interface reached equilibrium, and the carbon uptake varied with the square root of time. The carburization kinetics was well described by assuming that diffusion of carbon was coupled with rapid carbide precipitation and equilibrium partitioning of carbon between the metal and precipitates phases.
\end{abstract}

Keywords Steel · Carburization · Sodium · Diffusion

Fabien Rouillard

fabien.rouillard@cea.fr

Marie Romedenne

marie.romedenne@cea.fr

Daniel Monceau

daniel.monceau@ensiacet.fr

1 Den-Service de la Corrosion et du Comportement des Matériaux dans leur Environnement (SCCME), CEA, Université Paris-Saclay, 91191 Gif-sur-Yvette, France

2 Den-Service de Recherches Métallurgiques Appliquées (SRMA), CEA, Université Paris-Saclay, 91191 Gif-sur-Yvette, France

3 Den-Service d'Etudes Analytiques et Réactivité des Surfaces (SEARS), CEA, Université ParisSaclay, 91191 Gif-sur-Yvette, France

4 CIRIMAT, Université de Toulouse, CNRS, INPT, UPS, ENSIACET, 4, allée Emile Monso, BP 44362, 31030 Toulouse Cedex 4, France 


\section{Introduction}

In order to preserve uranium natural resources and to reduce nuclear waste, France has decided to develop a sodium-cooled fast reactor (SFR) prototype named ASTRID which running is expected around 2025. To control the nuclear reactor power, control rods with encapsulated neutron absorbent, $\mathrm{B}_{4} \mathrm{C}$, are used. In SFR, the cladding materials used for the $\mathrm{B}_{4} \mathrm{C}$ pellets are stainless steels [1]. Feedbacks from former French reactors, such as Phenix [2], showed that several areas of the stainless steel cladding suffered from mechanical rupture. Metallurgical analyses of these areas showed that they were strongly carburized [2]. At present, the assumed scenario is that $\mathrm{B}_{4} \mathrm{C}$ releases carbon into sodium which then reacts, diffuses and forms carbides through the stainless steel cladding thickness. Beyond a critical carburization level, the mechanical properties are strongly degraded. Lifetime models based on the carburization kinetics of stainless steels have been proposed in countries having developed SFRs in the past. All these previous studies proposed that the mechanical properties were highly degraded over a critical carbon concentration lying between 0.2 and $0.4 \mathrm{wt} \%$ [3]. In order to optimize the control rod lifetime in the reactor, the carburization mechanisms and kinetics have to be perfectly described. Since the exact carbon activity induced by $\mathrm{B}_{4} \mathrm{C}$ in stainless steel through liquid sodium is not well known, the carburation kinetics of three steels commonly used in French SFRs have been carried out in the present study, at a wellcontrolled unit carbon activity at $873 \mathrm{~K}$ (near reactor's service temperature). The objectives of these carburization tests are to compare the kinetics for the different steels and to propose a first kinetic model. In addition to the common analyses by metallography, glow discharge optical emission spectrometry (GDOES) and electron probe microanalysis (EPMA) were used to obtain quantitative data for carbon uptake as function of time, with depth profiling. Then, a model was proposed to describe the measured carburization kinetics by modifying the usual diffusion equation as done in Young et al.'s paper [4].

\section{Experimental Procedures}

Detailed chemical compositions of AIM1 (austenitic and strain-hardened 25\%), 316L (austenitic and annealed) and EM10 (ferritic and strain-hardened 25\%) used in the present study are given in Table 1 . For the carburization experiments, samples of $20 \times 20 \times 1 \mathrm{~mm}$ were cut. In order to measure the final carbon concentration reached in the samples at equilibrium, 150- $\mu$ m-thick strips were added. The specimens were exposed at $873 \mathrm{~K}$ for $500,1000,3000$ and $5000 \mathrm{~h}$ in a $2 \mathrm{~L} \mathrm{XC} 38$ mild steel grade vessel containing sodium. Before adding the samples, a zirconium strip was put into the sodium to purify it from oxygen and to reach a concentration lower than 5 ppm, in agreement with the level expected in French SFRs [5]. Then, several XC38 mild steel grade strips were inserted in purified sodium during $1000 \mathrm{~h}$ at $873 \mathrm{~K}$ to ensure that a unit carbon activity was reached in the sodium before exposing the samples. According to the relationship established by Thompson [6] on 
Table 1 Composition of studied alloys (in wt $\%$ ) analyzed by inductively coupled plasma-optical emission spectrometry (ICP-OES)

\begin{tabular}{|c|c|c|c|c|c|c|c|c|c|c|c|}
\hline \multirow[t]{2}{*}{ Steel } & \multicolumn{11}{|c|}{ Chemical composition (wt\%) } \\
\hline & $\mathrm{Cr}$ & $\mathrm{Ni}$ & Mo & $\mathrm{C}$ & $\mathrm{Ti}$ & Mn & $\mathrm{Co}$ & $\mathrm{Si}$ & $\mathrm{Cu}$ & $\mathrm{Al}$ & $\mathrm{Fe}$ \\
\hline AIM1 & 14.35 & 14.05 & 1.40 & 0.09 & 0.36 & 1.40 & 0.02 & 0.73 & 0.012 & 0.015 & Bal. \\
\hline $316 \mathrm{~L}$ & 16.55 & 10.52 & 2.05 & 0.03 & - & 1.55 & 0.12 & 0.18 & 0.24 & 0.022 & Bal. \\
\hline EM10 & 8.95 & 0.42 & $1.06^{\mathrm{a}}$ & 0.1 & 0.013 & 0.65 & 0.03 & $0.45^{\mathrm{a}}$ & 0.015 & 0.096 & Bal. \\
\hline
\end{tabular}

${ }^{a}$ Values from the material certificate (CEP Industrie)

the carbon solubility in sodium, only $5.5 \mathrm{ppm}$ of carbon is needed to reach a unit carbon activity in sodium at $873 \mathrm{~K}$. The carbon activity induced in sodium by the previous exposed procedure was verified by exposing $100-\mu \mathrm{m}$-thick nickel and 304 stainless steel tabs. Indeed, the activity of carbon as a function of carbon concentration is well known in these materials. Each specimen was weighed after three cleaning in ethanol to remove all metallic sodium from the surface of the samples. Their carbon content was also measured by infrared-inductive carbon combustion. Then, one part of the sample was etched with ammonium persulfate [10 g $\left(\mathrm{NH}_{4}\right)_{2} \mathrm{~S}_{2} \mathrm{O}_{8}, 100 \mathrm{~mL}$ water, $\left.10 \mathrm{~s}, 6 \mathrm{~V}\right]$ for metallographic examination. Carbon concentration profiles in the entire samples were established by electron probe microanalysis (SX 100 CAMECA) at $15 \mathrm{kV}$ and $20 \mathrm{nA}$ with the phi-rho-z method. The analytical crystal for $\mathrm{K} \alpha \mathrm{C}$ was LPC2 and liquid $\mathrm{N}_{2}$ cooling trap was used. Band scan mode $\left(2 \times 50 \mu \mathrm{m}^{2}\right)$ was used to average carbon concentration. Three quantitative profiles (step $4 \mu \mathrm{m}$ ) were realized in each sample aiming to a relative deviation of 5\%. Despite all the precautions, carbon pollution was observed on the surface due to samples' preparation and to the deposition in the vacuum chamber under electron beam. The level of pollution was evaluated to be $0.5 \mathrm{wt} \%$ for all steels from the analysis on the initial non-carburized specimen and subtracted to all the carbon profiles. Carbon concentration profiles in the extreme surface of the steels were carried out by GDOES at $850 \mathrm{~Pa}$ and $30 \mathrm{~W}$ with a Horiba Jobin Yvon GD-Profiler 2. The aims of this analysis were to identify any surface corrosion and to accurately quantify the surface carbon concentration. The concentration profiles were performed on a 4-mm-diameter area, with $2.5-\mathrm{nm}$ depth resolution.

\section{Results}

\section{Carbon Activity in Sodium}

Nickel and 304 stainless steel tabs were added to the carbon-saturated sodium in order to measure the carbon activity induced by XC38 mild steel strips. They were analyzed by infrared-induced carbon combustion to convert their carbon uptake into carbon activities using the appropriate relationship among those found in the 
literature [7-10]. These laws were developed under particular conditions (temperature, carbon activities and stainless steel grades). Therefore, Natesan et al.'s relationship [7] was used because it was the only law established up to unit carbon activity for alloys containing $8 \mathrm{wt} \%$ of chromium and from 2 to $22 \mathrm{wt} \%$ of nickel and at temperatures from 973 to $1173 \mathrm{~K}$ slightly higher than in our experiments. Table 2 indicates that the carbon concentrations reached in both $\mathrm{Ni}$ and 304 tabs were constant with time. Their values were close to $340 \mathrm{ppm}$ and $4.3 \mathrm{wt} \%$, respectively. They are in good agreement with unit carbon activity (with graphite as the reference state) for $\mathrm{Ni}$ [6] and 304 steel [7].

\section{Carburization}

\section{Carbon Uptake}

The evolution of the mass gain per unit of area for all steel grades as a function of exposure time is shown in Fig. 1a. After exposures in liquid sodium, careful attention should be given to the interpretation of these values since they reflect both the reactivity of the steel (dissolution, oxidation or carburization) and the sodium absorption. The comparison between the mass gains and the analyses of the carbon concentrations by infrared-induced carbon combustion for each exposure time attested that the mass gain was representative of the carbon uptake with a relative deviation of $4 \%$. The carbon uptake measured for the EM10 steel grade was twice larger as for the austenitic alloys. Besides, for all steels, the carburization rate decreased with time. Figure $1 \mathrm{~b}$ shows for the three steels that the weight gain kinetics were parabolic up to $1000 \mathrm{~h}$ and slowed down after.

Simultaneously, the mass gains per unit of area assimilated to the total carbon concentrations $\mathrm{C}^{\mathrm{TOT}}$ in the steel foils $(150 \mu \mathrm{m}$ thickness $)$ were measured. The values were $3.5 \pm 0.2,3.8 \pm 0.2$ and $3.1 \pm 0.2 \mathrm{wt} \%$ for AIM1, 316L and EM10, respectively, with error values estimated as described previously. These measurements corresponded to the final carbon concentration reached in the samples at equilibrium.

\section{Metallographic Examination}

The carburized layer can be observed in Fig. 2. For the austenitic steels, an homogeneous internal carburized layer was formed. Underneath, precipitated carbides were observed at grain boundaries. This grain boundary precipitation was not detectable for EM10. Only a continuous carburized layer was visible.

Table 2 Carbon concentration of $\mathrm{Ni}$ and of alloy 304 tabs as a function of time

\begin{tabular}{lccll}
\hline Foil & \multicolumn{4}{l}{ Carbon content $(w t \%)$} \\
\cline { 2 - 5 } & $500(\mathrm{~h})$ & $1000(\mathrm{~h})$ & $3000(\mathrm{~h})$ & $5000(\mathrm{~h})$ \\
\hline $\mathrm{Ni}$ & $0.030 \pm 0.001$ & $0.030 \pm 0.001$ & - & - \\
304 steel & $4.6 \pm 0.1$ & $4.5 \pm 0.1$ & $4.6 \pm 0.1$ & $4.5 \pm 0.1$ \\
\hline
\end{tabular}


A

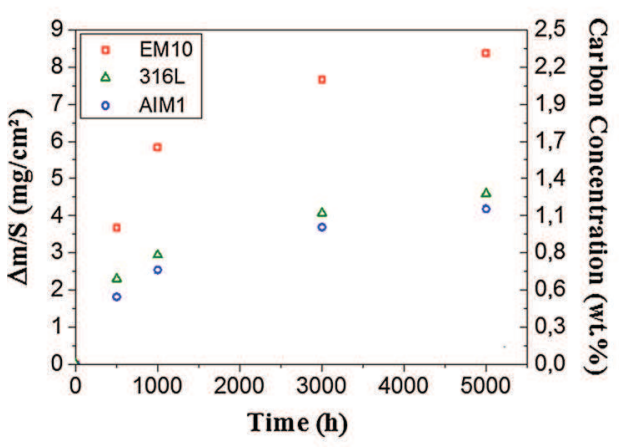

B

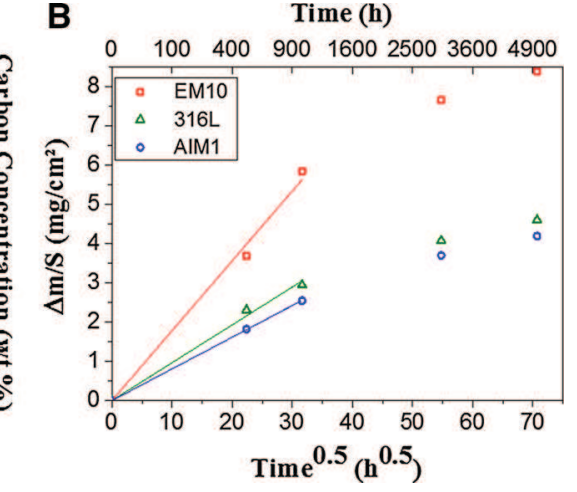

Fig. 1 a Measured mass gain per unit of area of EM10, AIM1 and 316L and deduced carbon concentration from mass gain as a function of exposure times in liquid sodium at $a_{\mathrm{c}}=1$ and $T=873 \mathrm{~K}$. b Corresponding parabolic plots

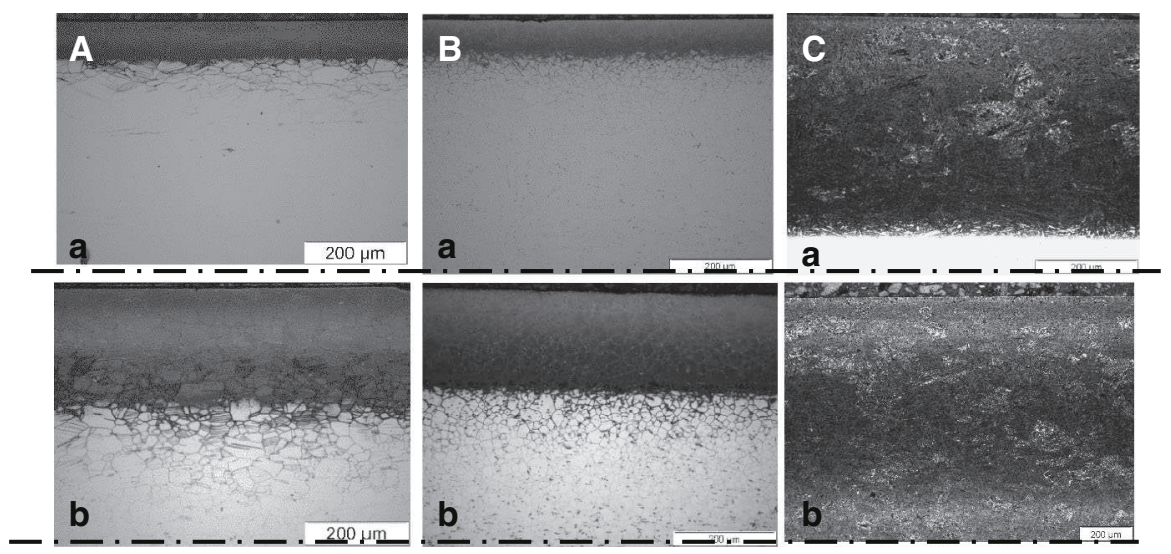

Fig. 2 Images of the revealed carburization layer for A AIM1, B 316L and C EM10 for (a) $500 \mathrm{~h}$ and (b) $5000 \mathrm{~h}$ obtained by optical microscopy

Simultaneously, the total carbon penetration depth (induced by intragranular and intergranular carburization) increased with time. Carburization of the whole sample thickness occurred between $500 \mathrm{~h}$ and $1000 \mathrm{~h}$ for EM10 and between $1000 \mathrm{~h}$ and $3000 \mathrm{~h}$ for AIM1 and 316L. These observations explain the deviation of the mass gain curves from the parabolic law observed for each grades in Fig. 1b.

\section{Carbon Concentration Profiles}

The distribution of carbon within the steel was measured by EPMA. The profiles shown in Fig. 3 confirm that the carbon penetration depths increased with time. For AIM1 (Fig. 3b), the carbon profile was not always perfectly monotonically decreasing. A few carbon enrichment areas appeared along the profile as observed at $160 \mu \mathrm{m}$ in depth for the sample exposed for $500 \mathrm{~h}$. WDS mapping of this area 

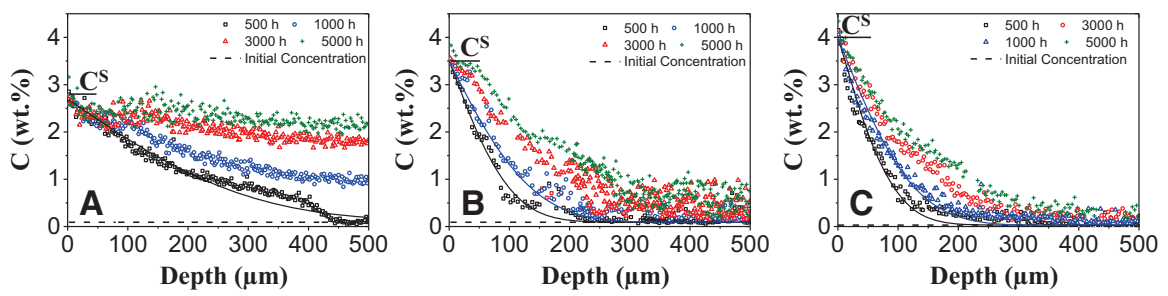

Fig. 3 Carbon concentration profiles measured by EPMA and fitting curves from Eq. (1) in a EM10, b AIM1 and c 316L steels as a function of exposure time in carburizing sodium at $873 \mathrm{~K}$

showed that they were due to the presence of large band of titanium carbides formed in the rolling direction. These carbides were already present in the initial steel state but grew after exposure in sodium. The carbon profiles are similar for $316 \mathrm{~L}$ without the carbon peaks induced by $\mathrm{TiC}$ formation and growth. Integration of the carbon concentration profiles in Fig. 3 led to overall carbon concentrations close to those measured in Fig. 1a with a relative deviation of $15 \%$. Interestingly, the carbon profiles by EPMA showed that the surface carbon concentration at the metalsodium interface, $\mathrm{C}^{\mathrm{S}}$, was constant with time except, maybe, after the higher exposure time, $5000 \mathrm{~h}$, where a higher $\mathrm{C}^{\mathrm{S}}$ was measured for all steels. It should be noticed that $\mathrm{C}^{\mathrm{S}}$ corresponded to the sum of the carbon in the matrix and the carbon trapped in the carbides at the sample surface. In order to get more accurate understanding of what occurred at the metal surface and to be more confident on the measured $\mathrm{C}^{\mathrm{S}}$ values, complementary high depth resolution GDOES profiles were carried out.

An example of GDOES profile is presented in Fig. 4 for EM10 steel after $3000 \mathrm{~h}$ in carbon-saturated sodium at $873 \mathrm{~K}$. The first $6 \mu \mathrm{m}$ near the surface were strongly

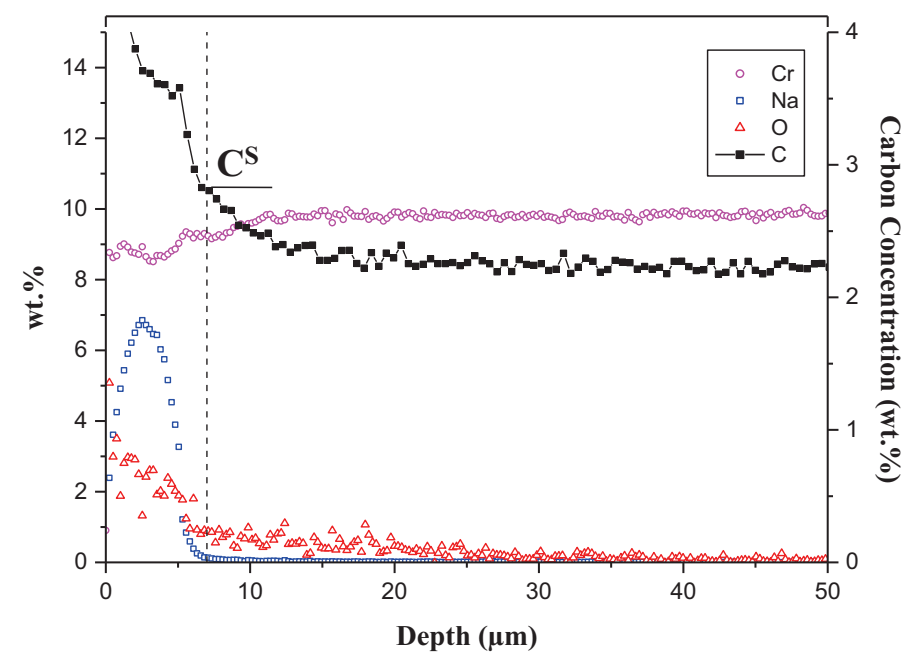

Fig. 4 Concentration profiles measured by GDOES through EM10 surface after exposure in sodium at $a_{\mathrm{c}}=1$ and $T=873 \mathrm{~K}$ for $3000 \mathrm{~h}$ 
enriched with $\mathrm{Na}, \mathrm{O}$ and $\mathrm{C}$. This affected zone has already been observed in the literature after steels exposure in sodium [11]. It was induced by the penetration of sodium into the steel surface during the experiment. Then, sodium has reacted with $\mathrm{CO}_{2}$ from the atmosphere to form sodium carbonates after removing the sample from the corrosion test. As a consequence, it is thought that $\mathrm{C}^{\mathrm{S}}$ measured in the sodium-affected zone is higher than the one which is effective during the reaction in liquid sodium.

From the GDOES profile Fig. $4, \mathrm{C}^{\mathrm{S}}$ (below the Na-affected zone) is equal to $2.7 \mathrm{wt} \%$ which is in quite good agreement with $\mathrm{C}^{\mathrm{S}}$ determined by EPMA. The higher $\mathrm{C}^{\mathrm{S}}$ value measured after $5000 \mathrm{~h}$ by EPMA might also have been overestimated by the sodium-affected zone.

\section{Discussion}

\section{Thermodynamics of Carburization}

The fact that the carbon concentration measured at the surface $\left(\mathrm{C}^{\mathrm{S}}\right)$ by EPMA and GDOES was constant with time and equal to the total and final carbon concentration $\left(C^{\mathrm{TOT}}\right)$ in the steel foils suggests that $\mathrm{C}^{\mathrm{S}}$ was the equilibrium concentration reached by the steels for an unit carbon activity in sodium. In Table 3, these values are compared with those obtained with ThermoCalc software, given with the steel compositions given in Table 1 and the most recent database for iron alloys TCFE8 $\left(\mathrm{C}^{\mathrm{EQ}}\right)$. For austenitic steels, they are also compared with the values calculated using Natesan et al.'s relationship [7]. Values of $C^{\mathrm{EQ}}$ predicted from the TCFE8 database were slightly lower than those measured experimentally for austenitic steels and significantly lower for the ferritic steel. For the austenitic steels, the predicted carbon concentration from Natesan et al.'s relationship [7] was $15 \%$ lower than the measured value for 316L steel and almost twice lower than the one for AIM1 steel. These higher predicted carbon concentrations could be explained by the fact that Natesan et al.'s equation [7] was established for steels with $8 \mathrm{wt} \%$ of nickel whereas 316L and AIM1 steels contained higher nickel content, 10 and $14 \mathrm{wt} \%$, respectively. For the ferritic steel, the equation found in the literature for determining the concentration of carbon at equilibrium [12] led to $\mathrm{C}^{\mathrm{EQ}}=10.7 \mathrm{wt} \%$ which highly overestimates the value obtained in the present experiments. This

Table 3 Comparison of the carbon concentrations at equilibrium for 316L, AIM1 and EM10 steels after exposure in sodium at ac $=1$ and $\mathrm{T}=873 \mathrm{~K}$

\begin{tabular}{llll}
\hline Carbon concentration (wt\%) & $316 \mathrm{~L}$ & AIM1 & EM10 \\
\hline $\mathrm{C}^{\mathrm{S}}$ (from EPMA) & $4.0 \pm 0.2$ & $3.5 \pm 0.1$ & $2.7 \pm 0.1$ \\
$\mathrm{C}^{\mathrm{TOT}}$ (foils) & $3.8 \pm 0.2$ & $3.5 \pm 0.2$ & $3.1 \pm 0.2$ \\
$\mathrm{C}^{\mathrm{EQ}}$ (ThermoCalc-TCFE8) & 3.5 & 3.0 & 2.0 \\
Natesan et al. [7] & 3.2 & 1.9 & $/$ \\
\hline
\end{tabular}


discrepancy was not surprising because this equation was defined from experiments at very low carbon activity. Finally, Table 3 highlights that the total carbon concentration $\mathrm{C}^{\mathrm{TOT}}$ was greater in $316 \mathrm{~L}$ steel than in AIM1 which was itself higher than in EM10. The same ranking was predicted by ThermoCalc calculations. Thus, the greater the chromium content in the steel was, the larger was the carbon absorption by the steel. Indeed, when carbon penetrated the steel, it was trapped forming chromium carbides.

\section{AIM1 Steel: Diffusion Coefficient of Carbon and Kinetics of Carburization}

In this part, the procedural steps used to determine the diffusion coefficient of carbon and the kinetics of carburization are described only for AIM1 steel. Nevertheless, results for all steels will be discussed. Firstly, the assessment of the apparent diffusion coefficient $\left(D_{\text {app }}\right)$ was achieved by fitting the EPMA carbon profiles with the solution of Fick's second law and by using the least square method. This method was used even though this diffusion model does not consider precipitation. This was done in order to compare the results with those obtained in the industry $[2,13,14]$ for basic time of life modelling. $D_{\text {app }}$ should be considered only as a fitting parameter which depends strongly on the alloy composition. Carbon was assumed to diffuse into a semi-infinite media with a constant surface concentration $\mathrm{C}^{\mathrm{S}}$. The evolution of the carbon concentration as a function of depth, $x$, and time, $t$, is given by the following expression Eq. (1) [15]:

$$
\left.\frac{\mathrm{C}(x, t)-\mathrm{C}_{0}}{\mathrm{C}^{\mathrm{S}}-\mathrm{C}_{0}}=\operatorname{erfc} \frac{x}{2 \sqrt{D_{\mathrm{app}} t}}\right)
$$

With $\mathrm{C}_{0}$, the initial concentration, and $\mathrm{C}^{\mathrm{S}}$, the carbon concentration at the metallic surface. For AIM1, $\mathrm{C}^{\mathrm{S}}$ was taken equal to $3.5 \mathrm{wt} \%$ based on the experimental results in Fig. 3b. Since the semi-infinite assumption was only valid for exposure times of 500 and $1000 \mathrm{~h}$, only these profiles were fitted. The resulting value of $D_{\text {app }}$ was $1.8 \pm 0.3 \times 10^{-11} \mathrm{~cm}^{2} \mathrm{~s}^{-1}$. Standard deviation was calculated taking an average of three carbon profiles at $500 \mathrm{~h}$ and four carbon profiles at $1000 \mathrm{~h}$. Calculated $D_{\text {app }}$ was in agreement with the values found by Meny [2] $\left(D_{\text {app }}=2.0 \times 10^{-11} \mathrm{~cm}^{2} \mathrm{~s}^{-1}\right)$ and Thorley and Hobdell [13] $\left(D_{\text {app }}=1.9 \times 10^{-11} \mathrm{~cm}^{2} \mathrm{~s}^{-1}\right)$ but lower than the one measured by Agarwala et al. [14] $\left(D_{\text {app }}=9.5 \times 10^{-11} \mathrm{~cm}^{2} \mathrm{~s}^{-1}\right)$ at $873 \mathrm{~K}$ in high carburizing sodium for 316 steel grades. The apparent diffusion coefficient evaluated from this simple approach was much lower than the diffusion coefficient of carbon extrapolated from high temperature data in austenite [16] validated at lower temperatures [17], $D_{\mathrm{c}}=5.6 \times 10^{-10} \mathrm{~cm}^{2} \mathrm{~s}^{-1}$ at $873 \mathrm{~K}$. This observation was not surprising and was always found for steels containing strong carbide formers, such as chromium.

As carbon diffused in the alloy and reacted with chromium to form carbides, Eq. (1) should not be applied in this system. In this configuration, it seemed more relevant to 
use the Wagner's treatment of internal oxidation [18]. In this model, it was assumed that all chromium was precipitated into carbides in the carbide precipitation zone and that carbon was the only element to diffuse (Eq. 2). Equation (2) was verified by taking $D_{\mathrm{c}}=5.6 \times 10^{-10} \mathrm{~cm}^{2} \mathrm{~s}^{-1}[16]$, the carbon diffusion coefficient in austenite, $D_{\mathrm{Cr}}=5.0 \times 10^{-17} \mathrm{~cm}^{2} \mathrm{~s}^{-1}$ [19], the chromium diffusion coefficient in austenite, $N_{\mathrm{C}}^{(\mathrm{S})}=4.8 \times 10^{-3}$ at. $\%$, the solute carbon at the alloy surface and $N_{\mathrm{Cr}}^{(0)}=15$ at. $\%$, the chromium concentration in the substrate. $D_{\mathrm{C}} N_{\mathrm{C}}^{(\mathrm{S})} \approx 10^{-12} \mathrm{~cm}^{2} \mathrm{~s}^{-1}$ and $D_{\mathrm{Cr}^{-}}$ $N_{\mathrm{Cr}}^{(0)} \approx 10^{-16} \mathrm{~cm}^{2} \mathrm{~s}^{-1}$. The internal carburization zone growth kinetics can be determined using Eq. (3) where $X_{\mathrm{c}}$ corresponds to the homogeneous carburization depth, $k_{\mathrm{p}}^{\mathrm{c}}$ the internal carburization rate constant and the exposure time. From Eq. (3) and Fig. 2, $k_{\mathrm{p}}^{\mathrm{c}}=1.7 \times 10^{-11} \mathrm{~cm}^{2} \mathrm{~s}^{-1}$. Application of Eq. (4) by taking $v$, the stoichiometric coefficient of the carbide $\mathrm{CrC}_{\mathrm{v}}$ equal to $3 / 7$, led to the experimental value of $D_{\mathrm{c}}=2.3 \times 10^{-8} \mathrm{~cm}^{2} \mathrm{~s}^{-1}$. This value is 50 times higher than the diffusion coefficient of carbon in austenite [16].

$$
\begin{gathered}
D_{\mathrm{C}} N_{\mathrm{C}}^{(\mathrm{S})} \gg D_{\mathrm{Cr}} N_{\mathrm{Cr}}^{(0)} \\
X_{\mathrm{C}}^{2}=2 k_{\mathrm{p}}^{\mathrm{C}} t \\
D_{\mathrm{c}}=\frac{v k_{\mathrm{p}}^{\mathrm{p}} N_{\mathrm{Cr}}^{(0)}}{N_{\mathrm{C}}^{(\mathrm{S})}}
\end{gathered}
$$

The reason why Wagner's model failed to describe the observed carburization kinetics was likely that not all chromium was trapped into carbides. The carburization model proposed recently by Young et al. [4] for the carburization of 9-12Cr steels in high temperature $\mathrm{CO}_{2}$ took into consideration this effect. In their model, it was assumed that diffusion of carbon was coupled with rapid carbide precipitation and equilibrium partitioning of carbon between the metal and precipitates phases. From this assumption, Fick's second law was modified according to Eq. (5) by introducing $\beta$, the constant ratio coefficient between the overall carbon concentration $\mathrm{C}_{\mathrm{C}}^{\mathrm{T}}$ in the substrate and the solute carbon concentration $\mathrm{C}_{\mathrm{C}}^{\mathrm{M}}$ (Eq. 6).

$$
\begin{gathered}
\frac{\partial C_{\mathrm{c}}^{\mathrm{M}}}{\partial t}=\frac{D_{\mathrm{c}}}{1+\beta} \frac{\partial^{2} C_{\mathrm{c}}^{\mathrm{M}}}{\partial x^{2}} \\
\mathrm{C}_{\mathrm{C}}^{\mathrm{T}}=\beta \mathrm{C}_{\mathrm{C}}^{\mathrm{M}}
\end{gathered}
$$

ThermoCalc was used to obtain the evolution of $\beta$ with the overall carbon concentration $C_{C}^{T}$ (Fig. 5). Since the fit of the carbon profile in Fig. $3 b$ was optimized for the first $50 \mu \mathrm{m}$, that is to say between 3.5 and $2 \mathrm{wt} \%$, an average of the $\beta$ value expected in this carbon concentration range was taken. Application of Eq. (5) with an average $\beta=66$ led to $D_{\mathrm{c}}=1.2 \pm 0.5 \times 10^{-9} \mathrm{~cm}^{2} \mathrm{~s}^{-1}$ which was only about twice higher than the carbon diffusion coefficient expected in austenite at $873 \mathrm{~K}$ from [16]. 
Fig. 5 Evolution of $\beta$ with carbon concentration for AIM1 steel composition simulated with ThermoCalc at $873 \mathrm{~K}$ (TCFE8 database)

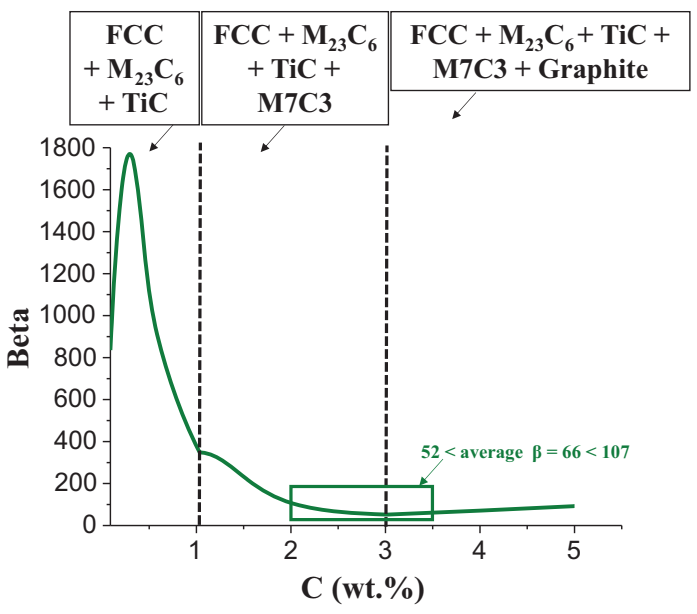

With the same method for 316L and EM10, Eq. (5) led to respective measured $D_{\mathrm{c}}(316 \mathrm{~L})=4.4 \pm 0.4 \times 10^{-10} \mathrm{~cm}^{2} \mathrm{~s}^{-1}$ with an average $\beta=46$ and $D_{\mathrm{c}}$ $($ EM10 $)=2.0 \pm 0.4 \times 10^{-7} \mathrm{~cm}^{2} \mathrm{~s}^{-1}$ with an average $\beta=1395$. These last values were in very good agreement with the carbon diffusion coefficients expected in austenite at $873 \mathrm{~K}$ from [16], $5.6 \times 10^{-10} \mathrm{~cm}^{2} \mathrm{~s}^{-1}$, and in ferrite at $873 \mathrm{~K}$ from [20], $2.2 \times 10^{-7} \mathrm{~cm}^{2} \mathrm{~s}^{-1}$. As a consequence of the good description of the carburization kinetics of the studied steels by Young et al.'s model, $D_{\text {app }}$, the useful apparent carbon diffusion coefficient for lifetime prediction, could be estimated in carburizing $\mathrm{Na}\left(a_{\mathrm{C}}=1\right)$ at $873 \mathrm{~K}$ for different steel compositions using the appropriate $D_{\mathrm{c}}$ and $\beta$ values.

\section{Conclusions}

1. The initial kinetics of carbon uptake was parabolic for the three alloys, before slowing down when the carbon reached the center of the samples.

2. The carbon uptake increased with the chromium content.

3. Faster carbon diffusion was found for the ferritic steel than for the austenitic steels.

4. The carburization kinetics was well described assuming the diffusion of carbon coupled with rapid carbide precipitation and equilibrium partitioning of carbon between the metal and precipitates phases. As a consequence, the carburization kinetics could be predicted with the application of the second Fick's law using an apparent diffusion coefficient of carbon which took into account the carbides precipitation.

Acknowledgements The authors are grateful to CEA, EDF and AREVA for funding this work. 


\section{References}

1. J. M. Escleine and S. Lansiart, Internal CEA report, SESC/LLCC 08-008 (2008).

2. L. Meny, Internal CEA report, SEDC/STAC 82/3851 (1982).

3. J. L. Krankota, Journal of Engineering Materials and Technology 98, (1), 1976 (9).

4. D. Young, P. Huczkowski, T. Olszewski, T. Hüttel, L. Singheiser and W. J. Quadakkers, Corrosion Science 88, 2014 (161).

5. J. Guidez, Phénix le retour d'expérience, (CEA, France, 2013), p. 225.

6. R. Thompson, Carbon Solubility and Solute species in Liquid Sodium, (AERE, Harwell, Oxon, 1980).

7. K. Natesan and T. F. Kassner, Metallurgical Transactions 4, 1973 (2557).

8. M. Menken and J. Jung, Survey on Investifations on Carbon Chemistry and Transfer in Sodium, (INTERATOM, Bergisch Gladbach, 1980).

9. R. Pillai, Journal of Materials Engineering and Performance 20, (7), 2011 (1140)

10. V. H. Tuma, P. Gröbner and K. Löbl, Archiv für das Eisenhüttenwesen 40, 1969 (727).

11. S. Hemery, Influence du sodium liquide sur le comportement mécanique de l'acier T91. PhD Thesis, Ecole Centrale Paris (2013).

12. O. K. Chopra, K. Natesan and T. F. Kassner, Journal of Nuclear Materials 96, 1981 (269).

13. A. W. Thorley and M. R. Hobdell, UKAEA Northern division report, ND-R-983 (1984).

14. R. P. Agarwala, M. C. Naik, M. S. Anand and A. R. Paul, Journal of Nuclear Materials 36, 1970 (41).

15. J. Crank, The Mathematics of Diffusion, (Oxford University Press Inc., New York, 1976), p. 32.

16. J. Agren, Scripta Metallurgica 20, 1986 (1507).

17. P. Thibaux, A. Métenier and C. Xhoffer, Metallurgical and Materials Transactions A 38A, 2007 (1169).

18. C. Wagner, Zeitschrift fur Elektrochemie 63, 1959 (772-782).

19. A. W. Bowen and G. M. Leak, Metallurgical Transactions 1, 1970 (1695).

20. J. R. G. Silva and R. B. McLellan, Materials Science and Engineering 26, 1976 (83). 